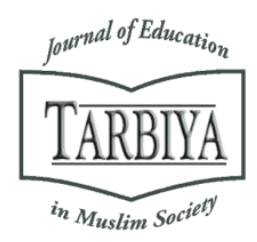

Available online at TARBIYA: Journal of Education in Muslim Society Website:

http://journal.uinjkt.ac.id/index.php/tarbiya

TARBIYA: Journal of Education in Muslim Society, 6(1), 2019, 69-75

\title{
ABILITY OF MATHEMATICAL GENERALISATION THINKING OF MATHEMATICS EDUCATION STUDENTS
}

\author{
Maifalinda Fatra ${ }^{1}$, Lilis Marina Angraini ${ }^{2}$, M. Anang Jatmiko ${ }^{1}$ \\ ${ }^{1}$ Syarif Hidayatullah State Islamic University of Jakarta, Indonesia \\ 2 Islamic University of Riau, Indonesia \\ E-mail: maifalinda.fatra@uinjkt.ac.id
}

Received: $13^{\text {th }}$ April 2019; Revised: $28^{\text {th }}$ May 2019; Accepted: $28^{\text {th }}$ June 2019

Abstract

The main objectives of this study are: 1) describing and analyzing the mathematical generalization ability of mathematics education students at State Islamic University (UIN) in Indonesia, 2) investigating the differences in mathematical generalization abilities of mathematics education students across State Islamic University (UIN) in Indonesia. The study was conducted at 6 UIN in Indonesia with a sample of 5th semester students using the survey method. The results of this study indicate that: 1) The ability of mathematical generalizations thinking of Mathematics Education students from 6 state Islamic universities in Indonesia can be seen from the average value of each sample. The average mathematical generalization of Syarif Hidayatullah State Islamic University in Jakarta is higher high than the other 5 state Islamic universities, with the average value of 61.31.2) There is no difference in the ability of mathematical generalization thinking among mathematics educations students of State Islamic University (UIN) in Indonesia.

Keywords: mathematical reasoning; mathematical generalisation thinking

\section{Abstrak}

Tujuan utama dari penelitian ini adalah: 1) mendeskripsikan dan menganalisis kemampuan generalisasi matematika siswa pendidikan matematika di Universitas Islam Negeri (UIN) di Indonesia, 2) menyelidiki perbedaan kemampuan generalisasi matematika siswa pendidikan matematika di Universitas Islam Negeri (UIN) ) di Indonesia. Penelitian ini dilakukan di 6 UIN di Indonesia dengan sampel mahasiswa semester 5 menggunakan metode survei. Hasil penelitian ini menunjukkan bahwa: 1) Kemampuan berpikir generalisasi matematika siswa Pendidikan Matematika dari 6 universitas Islam negeri di Indonesia dapat dilihat dari nilai rata-rata setiap sampel. Generalisasi matematika rata-rata dari Universitas Islam Negeri Syarif Hidayatullah di Jakarta lebih tinggi daripada 5 universitas Islam negeri lainnya, dengan nilai ratarata 61,31.2) Tidak ada perbedaan kemampuan berpikir generalisasi matematika di kalangan mahasiswa pendidikan matematika Universitas Islam Negeri (UIN) di Indonesia.

Kata kunci: penalaran matematika; pemikiran generalisasi matematika

How to Cite : Fatra, M., Angraini, L. M., Jatmiko, M. A. (2019). Ability of Mathematical Generalisation Thinking of Mathematics Education Students. TARBIYA: Journal of Education in Muslim Society, 6(1), 69-75.

doi:10.15408/tjems.v6i1.12315.

Permalink/DOI: http://dx.doi.org/10.15408/tjems.v6i1.12315

TARBIYA: Journal of Education in Muslim Society, P-ISSN: 2356-1416, e-ISSN: 2442-9848

This is an open access article under CC-BY-SA license (https://creativecommons.org/licenses/by-sa/4.0/) 


\section{Introduction}

In line with the need for human resources that have the ability to reflect critically, since the beginning of the 21st century there has been a paradigm shift in learning in Indonesia, from teacher-centered learning to student-centered learning. Learning that initially focuses on memorization changed to learning that uses thinking and understanding. This was marked by the existence of Competency based curriculum in 2004, School based curriculum in 2006, and the Curriculum 2013.

The change in the paradigm above shows that there is a desire of the Indonesian government to produce high-quality human resources through learning that develops thinking skills in schools. Thinking skills that can be developed in schools include high-level thinking skill that contain the ability to think critically and creatively. One type of learning that develops high-level thinking skills is learning that invites students to carry out various activities, for example: analyzing, evaluating, and drawing the right conclusions on a complex problem.

The need for this ability is closely related to the present situation that are dynamic, rapidly changing, and not easily predicted. Moreover, these abilities are needed by students to manage and use information to survive in conditions that are always changing, uncertain and competitive.

One of the subjects in school that is expected to develop such abilities is mathematics. This is not excessive considering that mathematics is the main subject received by students since elementary school. Besides that, mathematics also offer structured, organized, and logical concepts that can be applied to other subjects

Mathematical abilities are very important for students to support them to think better in making every decision regarding their lives. The mathematical abilities demanded by the National of Council Teachers of Mathematics (NCTM, 2000) consist of: mathematical communication mathematical reasoning (mathematical reasoning), mathematical problem solving , mathematical connection, and the formation of positive attitudes towards mathematics.

The mathematical abilities that must be possessed by students at the level of primary and secondary education must also be possessed by prospective teacher who will teach mathematics. The Committee on the Undergraduate Program in Mathematics (CUPM) (MAA, 2004) provides six basic recommendations for majors, programs, and courses in mathematics. One of the recommendations explained is that each course in mathematics should develop an activity that would help students in analytical development, reasoning, problem solving, and communication skills. The CUPM recommendation above explains that the task of mathematics education institution is preparing students to have mathematical reasoning abilities.

The faculty of education at higher education institution (LPTK) has the duty to produce professional teacher candidates, includes the Mathematics Education Department (PMTK). PMTK has the duty to produce professional teacher candidates who will teach mathematics in schools. PMTK is also responsible for preparing its students to have mathematical reasoning abilities. Mathematical reasoning ability is an ability that can be developed during the course, so that the lecturer should implement various strategies to support their students in developing their reasoning abilities.

According to Ansjar and Sembiring (2000) reasoning is the main characteristic of mathematics that cannot be separated from the activities of studying and learning mathematics or solving a mathematical problem. In line, Wahyudin (2008, pp. 35-36) states that 
reasoning ability is very important for understanding mathematics. Wahyudin further mentioned that reasoning systematically is a process that always takes place in the mind. This is because mathematics is a science that has axiomatic deductive characteristics, which require the ability to think and reason to understand it.

Moore and Stein suggested that the ability of mathematical skills of graduates at all levels of education is quite low, especially in the working atmosphere such as business and industry (Pranoto, 2013). The problem persist is not only on basic mathematical skills, but also the ability of graduates to express facts in solving problems or being involved in what is called high-level reasoning and thinking in mathematics.

A number of study report that high school students and even college students had difficulty in using strategies and consistent logic reasoning (Matlin, 2003). This means that many students have difficulty in solving mathematical problems include: connecting the initial knowledge (concepts that have been studied) to the problems faced, looking for strategies or ways to solve the problem and provide logical reasons for the answers given. As a results, many people think that mathematics is a difficult lesson.

Students often find difficult questions in which they are not able to solve in short time period, meanwhile students are expected to be able to solve the problem quickly. Students need to think or reason, guess or predict answers, look for a simple formula, then prove the truth. Students need to have thinking skills, so they can find the right way to solve the problems they face. In addition, students also need to construct ideas, draw conclusions and determine the truth of conclusions and their reasons.

The indication of the low mathematical reasoning ability of students was reported by Angraini, et al (2017). Their study suggested that a low mathematical reasoning ability caused by lecture activities that were less effective, even lectures often took place in one direction. In addition, low of mathematical ability may be due to the limited level of mathematical thinking skills possessed by high school and college graduates.

The mathematical reasoning ability examined in this study is generalization reasoning ability, namely the ability to draw conclusions in general based on limited data. For this reason, researchers conducted research related to the ability of mathematical generalization of Mathematics Education student at some state islamic universities in Indonesia. So that this study is entitled "Reasoning Ability of Mathematical Generalization of Mathematics Education Students in State Islamic University in Indonesia".

The main objective of this research is to describe and analyze the mathematical generalization ability of state Islamic universities' students in Indonesia. In particular, this study aims to: 1) Describe and analyze the mathematical generalization ability of mathematics education students the State Islamic University (UIN) in Indonesia. 2) Investigate the differences in mathematical generalization abilities of students in mathematics education study programs at several State Islamic Universities (UIN) in Indonesia.

\section{Literature Review}

Mathematical reasoning ability is the ability to express arguments that are essential for understanding mathematics (Turmudi, 2008, p. 7). Mathematical reasoning is a process that always takes place in the mind that must be developed consistently using various contexts. This means that mathematical reasoning is the ability to analyze mathematical situations that take place, then the results of the analyzing process reach a concrete conclusion. 
Reasoning is a thought process to connects facts that are known leading to a conclusion (Loc \& Uyen, 2014, p. 2). Mofidi, et al (2012) defines reasoning as the process of drawing logical conclusions based on existing facts and sources. Based on the two opinions above, it can be concluded that reasoning ability is needed to obtain a conclusion based on the facts before making a decision.

Furthermore, generalization is part of reasoning. Therefore, to understand the ability of generalization we must first understand what is meant by reasoning. Keraf (in Shadiq, 2004) states that reasoning is a thought process that connects facts that are known to lead to a conclusion. Reasoning is an activity, a process or a thinking activity to draw a conclusion or make a new statement that is correct based on some statements whose truths have been proven or assumed before. This is reinforced by the opinion of Shurter and Pierce (in Sumarmo, 1987: 31) reasoning is the process of achieving logical conclusions based on facts and relevant sources.

Ellis (2007) revealed that generalization is a process of reasoning based on examining things adequately and then drawing conclusions for all or most of them. In the learning process, when faced with a mathematical problem by examining the facts of a problem, a conclusion can be drawn from a concept. In line, Markman and Gentne (2001) suggested that generalization is the process of drawing conclusions starting with examining special circumstances towards general conclusions. The reasoning includes observing specific examples and finding patterns or rules that underlie them. Marzano and Pollock (2001) reveal that generalization is to state the pattern, determine the structure / data / picture / next tribe and formulate symbolic generality.

Generalization based on what principle occurs several times in certain conditions can be expected to always occur if the same conditions are met (Strachota, 2016). The results of reasoning in generalization are only a hope or a guess. Estimation or guesses are based on knowledge (experience) developed through specific facts.

Based on the description above, the concept of mathematical generalizations examined in this study is the ability to draw general conclusion based on observation of basic structure, patterns and general principles, and specific examples in accordance with the underlying rules. The indicators of the ability of mathematical generalizations in this study are: (1) symbolic expression of generality, students have been able to produce a general rule and pattern; (2) manipulation of generality, students are able to use the results of generalizations to solve problems.

\section{Method}

The survey approach employed in this study, aimed at generalizing the population based on sample data so that temporary conclusions can be made about the characteristics, behavior or attitudes of the population. The survey method was chosen to facilitate data acquisition of mathematical analogy reasoning abilities and mathematical generalization of Mathematics Education students in Indonesia.

The population in this study were all 5 th semester students of UIN Mathematics Education students in 6 cities (Syarif Hidayatullah UIN Jakarta, Sunan Gunung Djati UIN Bandung, Sunan Kalijaga UIN Yogyakarta, Sunan Ampel UIN Surabaya, UIN Alauddin Makassar, and UIN Sultan Syarif Kasim Riau). The students' participants were chosen randomly without considering their attainment. Since all the students has been taught using similar curriculum, it was then assumed that each class 
in 5th semester students of UIN Mathematics Education in 6 cities is a relatively homogeneous with heterogeneous characteristics of students in the class, meaning that there are students who have high, medium and low abilities.

The research conducted at Syarif Hidayatullah UIN Jakarta, Sunan Gunung Djati UIN Bandung, Sunan Kalijaga UIN Yogyakarta, Sunan Ampel UIN Surabaya, Alauddin UIN Makassar, and Sultan Syarif Kasim Riau State Islamic University aimed to see differences in analogy reasoning skills and mathematical generalization reasoning for Mathematics Education students. The participants were 203 $5^{\text {th }}$ semester students of Mathematics education; 35 students of students of Syarif Hidayatullah State Islamic University in Jakarta, 34 students of Sunan Gunung Djati State Islamic University in Bandung, 35 students of Sunan Kalijaga State Islamic University in Yogyakarta, 35 students of Sunan Ampel State Islamic University in Surabaya, 33 students of Alauddin State Islamic University in Makassar, and 31 students of Sultan Syarif Kasim State Islamic University in Riau.

Data obtained from the test results of the six sample groups in which all students has given the similar questions on mathematical generalization reasoning ability. There were two questions administered, each question consists of 2 parts with the subject matter of discussion of number theory. The validity of the instrument was tested for their kontent validity.

\section{Results and Discussion}

To find out the differences in mathematical generalization reasoning abilities of the Mathematics Education students of the six groups, a description test consisting of 5 items was administered. The test of mathematical generalization reasoning ability has been tested on $7^{\text {th }}$ semester students of Syarif Hidayatullah
State Islamic University, and its characteristics have been analyzed in the form of validity test, reliability test, difficulty level test, and problemdifferentiation test.

The data used in this study are the results of tests of mathematical generalization reasoning abilities of Mathematics Education students. After the six sample groups were given the problem set on mathematical generalization reasoning, the results of the test then the researchers calculated the prerequisite analysis and tested the hypothesis.

The results of the test show that there are differences in mean, median, mode, variance, standard deviation, slope and sharpness as presented in the Table 1 below.

Table 1. The differences of Mathematic

Generalization reasoning ability among students from 6 universities

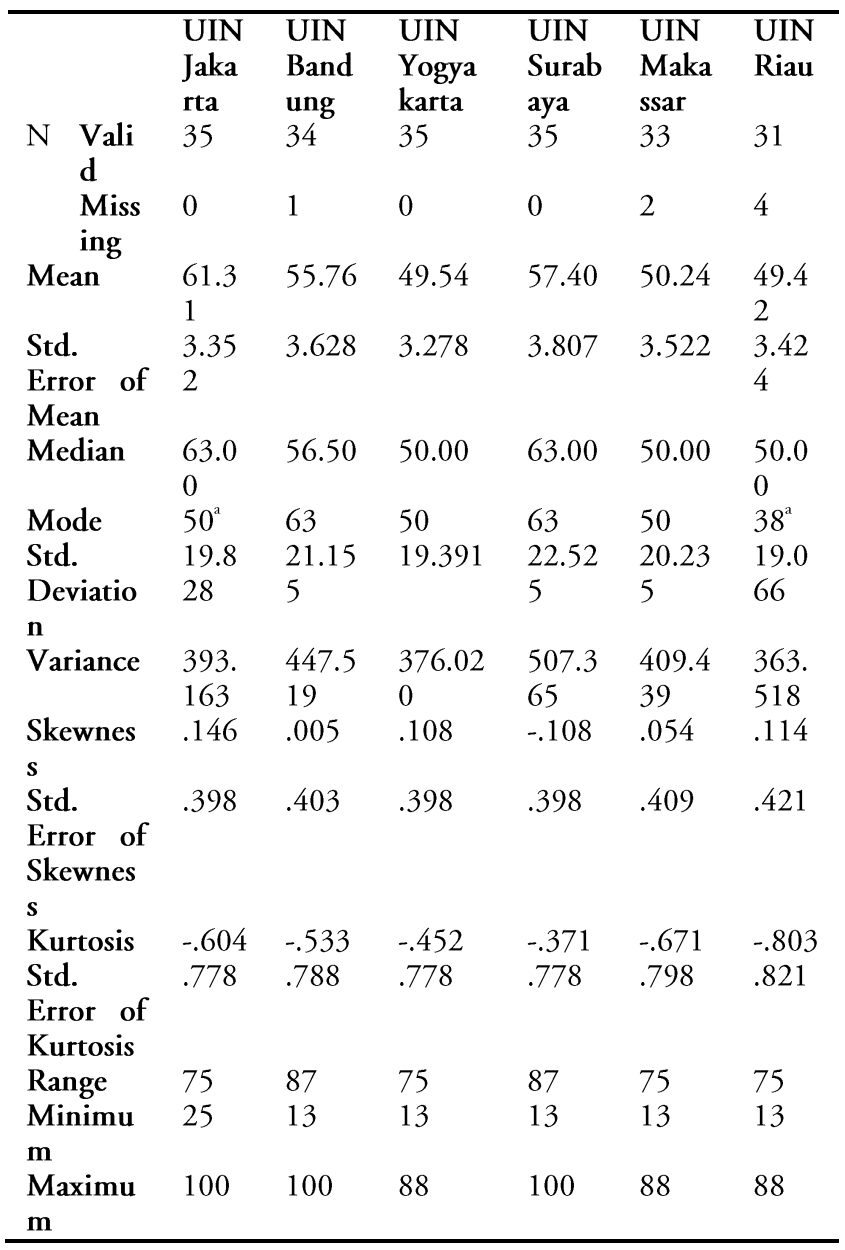


Table 1 above shows the comparison of mathematical generalization reasoning abilities of Mathematics Education students from 6 UIN in Indonesia. The average mathematical generalization score of students of Syarif Hidayatullah State Islamic University in Jakarta is the highest among all the participants, namely 61.31. Meanwhile the average score of Sultan Syarif Kasim Riau students is the lowest, at 49.42. The difference between the highest average score of mathematical generalization reasoning ability and the lowest is 11.89 . The median of mathematical generalization reasoning ability of Syarif Hidayatullah students in Jakarta and Sunan Ampel in Surabaya was the highest among all participant, with a median value of 63. On the contrary, the median of mathematical generalization reasoning abilities of Sultan Syarif Kasim students is the lowest compared to the other 3 UINs, around the point of 50 . The differences between the median of highest score and the lowest score is around the point of of 13 .

The mode value of mathematical generalization reasoning abilities of Sunan Gunung Djati Bandung and Sunan Ampel UIN Surabaya students is the highest compared to the other 4 UINs at the point of 63. While the mode value of mathematical generalization reasoning abilities of students of Sultan Kasim State Islamic Universty is the lowest around 38. The difference on the highest mode value of the mathematical generalization reasoning ability with the lowest is 25 .

In addition, to examine the differences of the average of mathematical generalization reasoning ability of Mathematics Education students from of 6 UIN, the researchers used hypotheses test. The results of hypothesis testing can be seen by looking at the significance values obtained. If the significance value is $>0.05$ then $\mathrm{H} 0$ is accepted. From the results of the one-way ANAVA test, it can be seen that the significance value is 0.079 (> 0.05). Then it can be concluded that there is no difference in mathematical generalization reasoning abilities of students in the mathematics education program at the State Islamic University (UIN) in Indonesia.

Based on the finding, it is interesting to note that only students from Syarif Hidayatullah Sate Islamic university got the average score more than 60, while the average score of students from other universities is between 50 to 60. Based on this results, it needs to examine further about the learning process carried out on UIN Jakarta, so that it is clear the cause of the high average value obtained by UIN Jakarta. Besides that, it also needs to carry study that focus in courses which contribute to the development of students' mathematical generalization abilities. This can be a joint evaluation between fellow mathematics education study programs at the UINs throughout Indonesia focus on the content of existing courses.

\section{Conclusion}

Based on the results of this study the following conclusions can be drawn: (1) The mathematical generalization ability of Mathematics Education students from 6 universities can be seen from the average score of the test given. The average of mathematical generalization reasoning ability of Syarif Hidayatullah UIN students in Jakarta is the highest compared to the other 5 UINs at the point of 61.31. Meanwhile the average score of mathematical generalization reasoning ability of UIN Sultan Syarif Kasim Riau students is the lowest compared to the other 5 UIN with the average value of around the point of 49.42 . The difference between the highest average score of mathematical generalization reasoning ability with the lowest is 11.89 . (2) There is no 
difference in mathematical generalization reasoning abilities of students in the mathematics education program at the State Islamic University (UIN) in Indonesia. The ANAVA test shows that the significance value of mathematical generalization reasoning ability is $0.079>0.05$.

\section{References}

Angraini, L.M., dkk. (2017). The effect of concept attainment model on mathematically critical thinking ability of the university students. Journal of Physics: Conference Series. 812(1), 012010. IOP Publishing.

Ansjar, M. Dan Sembiring (2000). Hakikat Pembelajaran MIPA dan Kiat Pembelajaran Matematika di Perguruan Tinggi. Jakarta: Dirjen Dikti Departemen Pendidikan Nasional.

Ellis, A. (2007). Connections between generalizing and justifying: students' reasoning with linier relationships. Journal for Research in Mathematics Education, 38(3), 194-229.

Keraf, G. (1982). Argumen dan Narasi: Komposisi Lanjutan III. Jakarta: Gramedia.

Loc \& Uyen. (2014). Using analogy in teaching mathematics: an investigation of mathematics education students in school of education - Can Tho University. International Journal of Education and Research, 2 (7).

Markman, A. \& Gentner, D . (2001). Learning and reasoning. Annual Review of Psychology, 51. Palo Alto, CA: Annual Review.

Marzano, R. J. \& Pollock, J. E. (2001). Standart based thinking and reasoning skill. In
Developing Minds a Resource Book for Teaching Thinking. Edited by Arthur L. Costa. USA. ASCD.

Mathematics Association of America. (2004). Undergraduate Programs and Courses in the Mathematical Sciences: CUPM Curriculum Guide 2004. Washington DC: The Mathematics Association of America Published.

Matlin, M.W. \& Geneseo, S. (2003). Cognition $\left(5^{\text {th }}\right.$ Ed). New Jersey: John Wiley $\&$ Sons Inc.

Mofidi, et al. (2012). Instruction of mathematical concepts through analogical reasoning skills. Indian Journal of Science and Technology. 5 (6).

National Council of Teachers of Mathematics. (2000). Principles and Standards for School Mathematics. Reston, VA: NCTM.

Pranoto, I. (2013, 26 Desember). Kasmaran Bermatematika. Dalam Harian Kompas.

Strachota, S. (2016). Conceptualizing generalization. IMVI Open Mathematical Education Notes. 6. 41-55.

Sumarmo, U. (1987). Kemampuan Pemahaman dan Penalaran Matematika Siswa Dikaitkan dengan Kemampuan Penalaran Logik Siswa dan Beberapa Unsur Proses Belajar Mengajar. Disertasi: FPS IKIP Bandung.

Turmudi. (2008). Landasan Filsafat dan Teori Pembelajaran Matematika (Berparadigma Eksploratif dan Investigatif. Jakarta: Leuser Cita Pustaka.

Wahyudin. (2008). Pembelajaran dan Modelmodel Pembelajaran: Pelengkap untuk Meningkatkan Kompetensi Pedagogis Para Guru dan Calon Guru Profesional. Bandung: Tidak Diterbitkan. 